\title{
EIderly Who Care for Elderly: DoubleVulnerability and Quality of Life
}

\author{
Letícia Decimo Flesch ${ }^{1}$ (D) https://orcid.org/0000-0002-9267-0516 \\ Samila Sathler Tavares Batistoni ${ }^{2}$ (D) https://orcid.org/0000-0002-8587-8298 \\ Anita Liberalesso Neri ${ }^{1}$ (D) https://orcid.org/0000-0002-6833-7668 \\ Meire Cachioni2 ${ }^{2}$ (D) https://orcid.org/0000-0001-5220-410X
}

\begin{abstract}
Elderly caregivers of other elderly people suffer from double vulnerability because they must deal with demands for care and for their own health. The objective of this study was to identify the association between double vulnerability and quality of life of elderly caregivers. The 148 participants were evaluated in relation to socio-demographic variables, quality of life, health selfassessment, perceived burden, measures of physical health of the caregiver and physical and cognitive vulnerability of the elderly who is the target of care. The hierarchical multivariate analysis showed that the elderly caregivers with the highest risk of worse quality of life were those with three or more diseases, with medium or high burden and with a worse health evaluation compared to the past. Greater health weakness is expected over the course of ageing; therefore, to study elderly caregivers, the perception of changes in health is a more pertinent measure than just the assessment of immediate health.
\end{abstract}

Keywords: caregivers, elderly, quality of life, vulnerability, gerontology

\section{Idosos que Cuidam de Idosos: Dupla Vulnerabilidade e Qualidade de Vida}

Resumo: Idosos que cuidam de outros idosos sofrem dupla vulnerabilidade, pois precisam lidar com demandas do cuidado e da própria saúde. O objetivo desse estudo foi identificar a associação entre dupla vulnerabilidade e qualidade de vida de idosos cuidadores. Os 148 participantes foram avaliados com relação às variáveis sociodemográficas, qualidade de vida, autoavaliação de saúde, sobrecarga percebida, medidas de saúde física do cuidador e de vulnerabilidade física e cognitiva do alvo de cuidados. A análise multivariada hierárquica mostrou que os cuidadores idosos com maior risco de pior qualidade de vida foram os com três ou mais doenças, com sobrecarga média ou alta e com pior avaliação de saúde comparada com o passado. É esperada uma maior debilidade na saúde ao longo do envelhecimento, portanto, talvez, para estudar cuidadores idosos, a percepção de mudanças na saúde seja uma medida mais pertinente do que apenas a avaliação da saúde imediata.

Palavras-chave: cuidadores, idosos, qualidade de vida, vulnerabilidade, gerontologia

\section{Ancianos que Cuidan a los Ancianos: Doble Vulnerabilidad y Calidad de Vida}

Resumen: Los ancianos que cuidan a otros ancianos sufren doble vulnerabilidad, pues necesitan lidiar con demandas del cuidado y de la propia salud. El objetivo de este estudio fue identificar la asociación entre doble vulnerabilidad y calidad de vida de ancianos cuidadores. Los 148 participantes fueron evaluados con relación a las variables sociodemográficas, calidad de vida, autoevaluación de salud, sobrecarga percibida, medidas de salud física del cuidador y de vulnerabilidad física y cognitiva de la persona que es objeto de cuidados. El análisis multivariado jerárquico mostró que los cuidadores ancianos con mayor riesgo de peor calidad de vida fueron los con tres o más enfermedades, con sobrecarga media o alta y con peor evaluación de salud comparada con el pasado. Se espera una mayor debilidad en la salud a lo largo del envejecimiento; por lo tanto, para estudiar cuidadores ancianos, la percepción de cambios en la salud es una medida más pertinente que sólo la evaluación de la salud inmediata.

Palabras clave: cuidadores, ancianos, calidad de vida, vulnerabilidad, gerontología

${ }^{1}$ Universidade Estadual de Campinas, Campinas-SP, Brazil
${ }^{2}$ Universidade de São Paulo, São Paulo-SP, Brazil

Article derived from the doctoral thesis of the first author under the supervision of the last author, defended in 2017, in the Postgraduate Program in Gerontology of the State University of Campinas - Unicamp'.

Support: Coordination for the Improvement of Higher Education Personnel (Coordenação de Aperfeiçoamento de Pessoal de Nivel Superior - Capes)

Correspondence address: Letícia Decimo Flesch. Universidade Estadual de Campinas, Campinas. Rua Tessália Vieira de Carvalho, 126 Cidade Universitária, Campinas-SP, Brazil. CEP. 13.081-970. E-mail: leticiadecimo@gmail.com
Revision studies emphasize that the physical and psychological vulnerability of the informal caregiver of the elderly has been well studied over the last few years (Adelman, Tmanova, Delgado, Dion, \& Lach, 2014; Fonareva \& Oken, 2014; van der Lee, Bakker, Duivenvoorden, \& Dröes, 2014). Studies have also been conducted with more specific populations of family caregivers, such as middleaged women inserted in the labor market with small children caring for elderly parents, the so-called sandwich generation (McGoldrick \& Shibusawa, 2016). 
With the ageing population, another profile of caregivers is increasing, although it is still little studied. Currently, it is common to find caregivers of elderly dependents who are also elderly. This role is usually assumed by the partner to be the person closest to the elderly with health impairment, a factor that causes the rest of the family to easily accept this choice, besides being socially established that between the couple there should be mutual care. The elderly caregiver may also be a son or a daughter who, driven by a sense of retribution for the care that the parents have given him or her, becomes responsible for the care of the older parents. Care, in a situation like this, is perceived as an obligation of the children and these have a debt to the parents (Braz \& Ciosak, 2009).

In a comparative study between young and elderly caregivers of Parkinson patients, older caregivers were more likely to have greater physical health impairments, however, young caregivers had lower levels of perceived reciprocity and reward in caring (Carter, Lyons, Stewart, Archbold, \& Scobee, 2010).

Regarding the general health of the caregiver, RöslerSchidlack, Stummer and Ostermann (2010) compared the health perception of young, middle-aged and older caregivers. They found that the group of elderly caregivers obtained higher scores on a scale that evaluated physical and mental health and lower scores of psychological burden compared to the younger ones. The authors explained this finding considering that only healthy older people can cope with the demands of the role of caregiver, so for older people who are already in poor health they are not expected to become primary caregivers.

A model for understanding the effects of care on elderly caregivers is the stress model of the caregiver of Pearlin, Mullan, Semple, and Skaff (1990). This model was developed in the 1990s and is widely used in research and interventions, and according to the perspective the present study is conducted. The model does not only seek to identify conditions that may be associated with the caregiver's stress, but how these conditions arise and how they relate to each other. This process involves the context of stress, stressors (divided into primary and secondary), stress mediators and the results or manifestations of stress (Pearlin et al., 1990).

Elderly people who care informally for other elderly people are subjected to two types of risks: (1) risks arising from the exercise of the role of caregiver and (2) risks arising from ageing itself. It is necessary that the specific characteristics of this group be better understood so that actions can be developed that aim at the well-being of the caregivers with this double vulnerability.

Given the importance and the current relevance of the theme, the objective of this study was to identify the relationship between double vulnerability and quality of life of elderly caregivers. In this research, the risks from exercising the role of caregiver were measured by the objective demands of care in the physical and cognitive domains (dependence on activities of daily living - ADLs and level of cognitive impairment of the care target) and perceived burden. The risks associated with ageing itself were measured by the physical health variables of the caregiver (fragility, number of chronic diseases and signs and symptoms) and health self assessment, according to Figure 1.

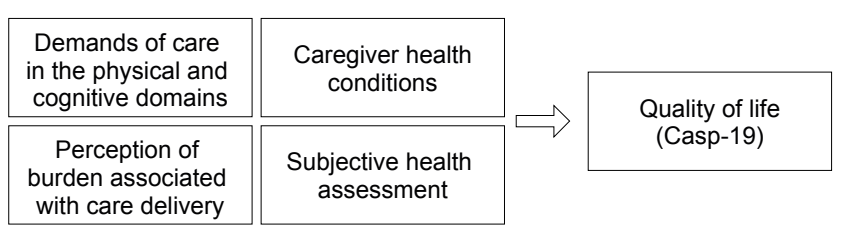

Figure 1. Study model.

\section{Method}

\section{Participants}

The data of this research come from the study "Psychological wellbeing of elderly people who look after other seniors in the family context" in development in the Faculty of Medical Sciences of the State University of Campinas. The aim of the project was to analyze the effects of caring for the physical and mental health of the caregiver, based on the model of stress and coping proposed by Pearlin et al. (1990).

Participants included 148 people aged 60 years and older who informally cared for other elderly people with physical or cognitive impairment. They were recruited for convenience in offices of geriatric doctors or related specialties (39.8\%); public services (48\%) and private (8.8\%) home care; and in the Family Health Program (3.4\%) in the cities of Campinas, Jundiaí, Indaiatuba, Vinhedo, Sorocaba, Itapetininga, São Paulo (in the state of São Paulo) and Recife (in the state of Pernambuco).

The inclusion criteria used in this study were: to be 60 years of age or older, to informally care for an elderly relative with some degree of dependency for at least six months, to agree to participate in the study and to sign the Term of Free and Informed Consent.

The exclusion criteria adopted: score below the cutoff score of the CASI-S (Cognitive Abilities Screening Instrument - Short Form) validated for Brazil by Damasceno et al. (2005). The cutoff point for cognitive impairment is 23 for $60-69$ years old (sensitivity of $76.7 \%$, specificity of $86.5 \%$, positive predictive value of 5.68 and negative of 0.27 ) and 20 for 70 years and over (sensitivity of $71.4 \%$, specificity of $97.1 \%$ (Damasceno et al., 2005).

The estimation of the sample size required to analyze the correlation between the scores of the scales used in the study was done using the Pearson correlation coefficient method, with Fisher's transformation, considering a significance level or alpha of $1 \%$, the test power of $90 \%$, null correlation of 0.10 , use of bilateral hypothesis test, and minimum correlation of 0.40 . Proc Power was used from the SAS software, which contains details on formulas and parameters (SAS/STAT User's Guide 2008). 
Among the caregivers surveyed, $77 \%$ were women. Age ranged from 60 to 86 years $(M=69.8, S D=7.1)$, and $46 \%$ had between 65 and 74 at the time of the interview. The sample had predominance of low schooling, $87 \%$ had between zero and four years of schooling. The sociodemographic data and the scoring of the scales are shown respectively in Table 1 and Table 2.

Table 1

Characterization of the sample regarding the care conditions and the socioeconomic conditions of the caregiver's families

\begin{tabular}{|c|c|c|c|c|c|}
\hline Variables & Conditions & $N$ & $\%$ & $M$ & $S D$ \\
\hline \multirow[t]{2}{*}{ Gender } & Male & 34 & 23.0 & & \\
\hline & Female & 114 & 77.0 & & \\
\hline \multirow[t]{3}{*}{ Age } & $60-64$ & 43 & 29.0 & 69.8 & 7.1 \\
\hline & $65-74$ & 68 & 46.0 & & \\
\hline & $>75$ & 37 & 25.0 & & \\
\hline \multirow{4}{*}{$\begin{array}{l}\text { Relationship to the elderly care } \\
\text { recipient }(N=148)\end{array}$} & Partner & 92 & 62.2 & 5.6 & 4.3 \\
\hline & Progenitor & 41 & 27.7 & & \\
\hline & Father / mother-in-law & 5 & 3.4 & & \\
\hline & Others & 10 & 6.9 & & \\
\hline \multirow{3}{*}{$\begin{array}{l}\text { Time from onset of care } \\
(N=145)\end{array}$} & $<2$ years & 42 & 28.5 & 4.5 & 4.1 \\
\hline & $2.0-4.9$ years & 52 & 36.0 & & \\
\hline & $>5$ years & 51 & 35.5 & & \\
\hline \multirow{4}{*}{$\begin{array}{l}\text { Main health disorder of the elderly } \\
\text { care recipient }(N=147)\end{array}$} & Dementia & 45 & 30.4 & & \\
\hline & Cerebrovascular disease & 30 & 20.3 & & \\
\hline & Immobility & 31 & 21.0 & & \\
\hline & Others & 41 & 28.3 & & \\
\hline \multirow{2}{*}{$\begin{array}{l}\text { Single caregiver } \\
(N=145)\end{array}$} & Yes & 74 & 51.0 & & \\
\hline & No & 71 & 49.0 & & \\
\hline \multirow{2}{*}{$\begin{array}{l}\text { Paid caregiver } \\
(N=147)\end{array}$} & Yes & 28 & 19.0 & & \\
\hline & No & 119 & 81.0 & & \\
\hline \multirow{4}{*}{$\begin{array}{l}\text { Paid caregiver status } \\
(N=28)\end{array}$} & Daytime caregiver & 8 & 29.7 & & \\
\hline & Maid & 12 & 44.5 & & \\
\hline & Nurse & 6 & 3.7 & & \\
\hline & Weekend caregiver & 1 & 22.1 & & \\
\hline \multirow{4}{*}{$\begin{array}{l}\text { Marital status } \\
(N=147)\end{array}$} & Married & 118 & 80.3 & & \\
\hline & Single & 14 & 9.5 & & \\
\hline & Widower & 9 & 6.1 & & \\
\hline & Divorced & 6 & 4.1 & & \\
\hline \multirow{3}{*}{$\begin{array}{l}\text { Monthly income in minimum } \\
\text { wages }(N=148)\end{array}$} & $0-3$ & 20 & 13.5 & 4.0 & 3.6 \\
\hline & 3.1 to 5.0 & 43 & 29.0 & & \\
\hline & $>5.1$ & 85 & 57.4 & & \\
\hline \multirow{3}{*}{$\begin{array}{l}\text { Years of schooling } \\
(N=145)\end{array}$} & 0 to 4 & 87 & 60.0 & 5.6 & 4.2 \\
\hline & 5 to 8 & 33 & 22.7 & & \\
\hline & $>9$ & 25 & 17.4 & & \\
\hline \multirow{2}{*}{$\begin{array}{l}\text { Paid caregiver } \\
(N=148)\end{array}$} & Yes & 21 & 14.2 & & \\
\hline & No & 127 & 85.8 & & \\
\hline \multirow{3}{*}{$\begin{array}{l}\text { Age of the elderly care recipient } \\
(N=148)\end{array}$} & $60-69$ & 20 & 13.5 & 81.2 & 9.8 \\
\hline & $70-79$ & 43 & 29.0 & & \\
\hline & $>80$ & 85 & 57.4 & & \\
\hline
\end{tabular}


Table 2

Characterization of caregivers in relation to quality of life, health variables, functionality of the elderly care recipient, health self-assessment and burden $(N=148)$

\begin{tabular}{|c|c|c|c|c|c|}
\hline Variables & Conditions & $N$ & $\%$ & $M$ & $S D$ \\
\hline \multicolumn{6}{|c|}{ Caregiver variables } \\
\hline \multirow[t]{3}{*}{ Total quality of life } & $<40$ & 50 & 33.8 & 42.8 & 8.8 \\
\hline & $41-47$ & 50 & 33.8 & & \\
\hline & $>48$ & 48 & 32.4 & & \\
\hline \multirow[t]{3}{*}{ Number of diseases } & 0 & 31 & 21.0 & 1.9 & 1.5 \\
\hline & $1-2$ & 69 & 46.6 & & \\
\hline & $>3$ & 48 & 2.4 & & \\
\hline \multirow[t]{3}{*}{ Number of symptoms } & 0 & 31 & 21.0 & 1.9 & 1.6 \\
\hline & $1-2$ & 75 & 50.7 & & \\
\hline & $>3$ & 42 & 28.4 & & \\
\hline \multirow[t]{3}{*}{ Fragility } & Robust & 28 & 19.9 & & \\
\hline & Pre-frail & 68 & 46.0 & & \\
\hline & Frail & 52 & 35.1 & & \\
\hline \multirow[t]{3}{*}{ Current health self-assessment } & Terrible / bad & 8 & 54.1 & & \\
\hline & Regular & 66 & 44.6 & & \\
\hline & Good / highly & 74 & 50.0 & & \\
\hline \multirow{3}{*}{$\begin{array}{l}\text { Health self-assessment } \\
\text { compared to the past }\end{array}$} & Worse & 54 & 36.5 & & \\
\hline & Equal & 71 & 48.0 & & \\
\hline & Better & 23 & 15.5 & & \\
\hline \multirow{3}{*}{$\begin{array}{l}\text { Health self-assessment } \\
\text { compared to the others a }\end{array}$} & Worse & 15 & 10.8 & & \\
\hline & Equal & 39 & 28.1 & & \\
\hline & Better & 85 & 61.2 & & \\
\hline \multirow[t]{3}{*}{ Total Caregiver burden } & $<19$ & 50 & 33.8 & 26.1 & 13.5 \\
\hline & $20-27$ & 48 & 32.4 & & \\
\hline & $>28$ & 50 & 33.8 & & \\
\hline \multicolumn{6}{|l|}{ Elderly care recipient variables } \\
\hline \multirow{3}{*}{$\begin{array}{l}\text { No. of BADLs and IADLs } \\
\text { that the elderly care recipient } \\
\text { is dependent }\end{array}$} & $0-6$ & 38 & 25.7 & & \\
\hline & $7-12$ & 61 & 41.2 & & \\
\hline & 13 & 49 & 33.1 & & \\
\hline \multirow{3}{*}{ CDR } & None / questionable & 66 & 44.6 & & \\
\hline & Mild / moderate & 36 & 24.3 & & \\
\hline & Serious & 46 & 31.1 & & \\
\hline
\end{tabular}

Note. ${ }^{\mathrm{a}} \mathrm{N}=139$

\section{Instruments}

\section{Caregiver-related variables and instruments}

Socioeconomic conditions of the caregiver. Questions regarding the characteristics of the caregiver: age (in years), sex (male or female), date of birth, schooling (incomplete and complete elementary I, incomplete and complete elementary II, incomplete and complete high school and incomplete and complete college education) marital status (married or living with partner, single, widowed, divorced or separated) and if the person has paid work. The items in this block were tested in the Fibra Study (Neri et al., 2013).

Physical health of the caregiver. Evaluated by a list of self-reported diseases for the question: "Have any doctors ever told you that you have the following diseases?" A list of signs and symptoms that have occurred in the last 12 months. The list of signs and symptoms was based on that used in the SABE study (Lebrão \& Duarte, 2003) and replicated in the Fibra Study (Neri et al., 2013). A measure of fragility validated by Nunes, Duarte, Santos and Lebrão (2015) was also used according to Fried et al. (2001) criteria. It consists of five questions about weight loss, decreased strength, reduced physical activity, walking speed and fatigue. These measures are answered in a dichotomous way (yes or no). The instrument had good internal consistency for decreasing walking speed $(\alpha=0.77)$ and decreased physical strength $(\alpha=0.72)$ and lower internal consistency for low physical activity $(\alpha=0.63)$. To identify pre-frail individuals the sensitivity was $89.7 \%$ and the specificity was $24.3 \%$. For fragile individuals the sensitivity and specificity were $63.2 \%$ and $71.6 \%$, respectively). It consists of five questions about weight loss, decreased strength, reduced physical activity, walking speed and fatigue. These measures are answered in a dichotomous way (yes or no). The instrument had good internal consistency for decreasing walking speed $(\alpha=0.77)$ 
and decreased physical strength $(\alpha=0.72)$ and lower internal consistency for low physical activity $(\alpha=0.63)$. To identify pre-frail individuals the sensitivity was $89.7 \%$ and the specificity was $24.3 \%$. For fragile individuals the sensitivity and specificity were $63.2 \%$ and $71.6 \%$, respectively.

Health self-assessment. Suggested by Bowling (2005) and tested in the Fibra Study (Neri et al., 2013). Contains a question about how the participant evaluates his / her health in general, another on how he / she evaluates the care of his / her health (alternatives: $1=$ very bad, $2=$ bad, $3=$ regular, $4=\operatorname{good}$ and $5=$ very good), a question about how he $/$ she evaluates his / her health compared a year ago, and one about how he / she evaluates his / her health compared to other people of the same age (responses: $1=$ worse, $2=$ equal and $3=$ better).

Socioeconomic conditions of the caregiver's family. Questions concerning housing arrangement (number of persons in residence, degree of relationship and existence and care of children), family income (financial contribution of the elderly who are cared for, if the income is enough for the needs of the family and the treatment the elderly who are cared for and the gross family income).

Satisfaction of the needs of psychological domains of quality of life. CASP-19 is a measure that involves four domains: control, autonomy, pleasure and self-realization. It consists of 19 items answered by a four-point Likert scale (never, sometimes, almost always and always). It was developed for the elderly population based on Maslow's basic needs theory (Hyde, Wiggins, Higgs, \& Blane, 2003). It is being validated for Brazil in the CASP-19 study: Semanticcultural adaptation and evidence of construct and convergent validity in Brazilian elderly $(\alpha=0.73)$.

Caregiver burden. An instrument consisting of 22 questions whose answers comprise a five-point scale (never $=0$ and always $=4$ ). It was developed by Zarit, Reever and Bach-Peterson (1980) and translated and validated for the Brazilian population by Scazufca (2002) $(\alpha=0.87)$.

\section{Variables related to the elderly care recipient}

Characteristics of the elderly care recipient. Age, primary health problem, whether the caregiver resides with the elderly care recipient, and whether the caregiver is the primary and / or sole responsible for him/ her.

Degree of dependency of the elderly care recipient in instrumental activities of daily living (IADLs) and basic activities of daily living (BADLs). The Brazilian version of the Lawton and Brody scale (1969), Brito, Nunes and Yuaso (2007): evaluates the use of telephone, transportation, shopping, preparing food, doing domestic tasks, using medication and handling money. The respondent informs if, for each of the actions, the patient is independent, needs help or is totally independent. In a study by Santos and Virtuoso Júnior $(2008)$ presented good reproducibility $(\operatorname{Ricc}=0.89)$ and objectivity $($ Ricc $=0.80)$.

The Katz, Ford, Moskowitz, Jackson and Jaffe (1963) Scale was validated for the Brazilian population by Lino,
Pereira, Camacho, Ribeiro Filho and Buksman (2008) and, in this study, Chronbach's alpha ranged from 0.80 to 0.92 . Evaluates activities: bathing, dressing, using the toilet, transference, continence and feeding. The caregiver indicates whether the patient needs partial or total help or does not need help for each of these activities.

Cognition of the elderly care recipient. Cognition of the elderly care recipient. Clinical Dementia Rating (CDR): evaluates cognitive losses through six categories: memory, counseling, problem's judgment or solving, community relations, home or leisure activities, and personal care. Each category is classified according to the degree of impairment (no change, questionable, mild, moderate and severe). This evaluation is performed in an interview with a person close to the patient. CDR validation for Portuguese was performed in the study by Montaño and Ramos (2005) and showed sensitivity of $91.2 \%$ and specificity of $100 \%$ with positive predictive value of $100 \%$ and negative of $97.6 \%$.

\section{Procedure}

Data collection. Participants were invited to participate in the research at the health service in which the elderly care recipient is cared for. After signing the Term of Free and Informed Consent, the research protocol was applied, which lasted approximately one hour. The interviews were carried out at the place of the service $(38.5 \%)$ or at home $(61.5 \%)$, when it was not possible for the caregiver to remain in the service. The conduction of interviews at the service was authorized by the responsible professionals through a printed document. Seven trained interviewers, from an academic master's and doctoral program in Gerontology, conducted the interviews at places and times previously agreed upon with the participants. After the interview, participants were offered a booklet with instructions that can facilitate communication with older people.

Data analysis. Descriptive analysis was performed initially to characterize the sample. Chi-square and Fisher's exact tests were used to compare the categorical variables. For the comparison of the numerical variables between three groups, the Kruskal-Wallis test was used, due to the absence of normal distribution of the variables. Finally, the multivariate hierarchical logistic regression analysis was used to study the factors associated with quality of life, using a Stepwise criterion for selecting variables. The significance level adopted for the statistical tests was $5 \%$.

\section{Ethical Considerations}

The project was submitted and approved by the Research Ethics Committee (CAAE n. 35868514.8.0000.5404).

\section{Results}

The caregiver and care recipients' health data are shown in Table 2. It can be noted that the dependence of care 
recipients on activities of daily living is high. Caregivers' health also deserves attention, almost half of caregivers have at least one chronic diseases and almost $80 \%$ of caregivers have at least one sign or symptom.

The results of this research identified that in relation to the comparison between the terciles of quality of life, there were no statistically significant differences between the terciles of the total quality of life score and the gender and age of the caregiver. It was observed a higher frequency of greater dependence of the elderly who are cared for in daily life activities in caregivers with worse quality of life.
However, there were no statistically significant differences between the cognitive functioning of the elderly who are cared for and the quality of life of the caregiver.

Among the caregivers who reported worse quality of life, it was found a higher frequency of fragile caregivers with three or more chronic diseases and symptoms. There was a statistically higher percentage of caregivers with worse quality of life who reported higher burden and worse health self-assessment. The results of the univariate logistic regression analysis of the relationships between the terciles of Casp-19 are presented in Table 3.

Table 3

Results of the univariate logistic regression analysis of the relationships between the Casp-19 terciles, physical health, elderly care recipient dependence, burden and health self-assessment $(N=148)$

\begin{tabular}{|c|c|c|c|c|}
\hline Variable & Categories & $p$ & O.R.* & CI 95\% O.R.* \\
\hline Number of diseases & $\begin{array}{c}0 \text { (ref.) } \\
1-2 \\
\geq 3\end{array}$ & $\begin{array}{c}- \\
0.067 \\
0.001\end{array}$ & $\begin{array}{l}1.00 \\
2.12 \\
4.30\end{array}$ & $\begin{array}{c}- \\
0.95-4.73 \\
1.80-10.28\end{array}$ \\
\hline Number of symptoms & $\begin{array}{c}0 \text { (ref.) } \\
1-2 \\
\geq 3\end{array}$ & $\begin{array}{c}- \\
0.381 \\
0.002\end{array}$ & $\begin{array}{l}1.00 \\
1.42 \\
3.97\end{array}$ & $\begin{array}{c}- \\
0.65-3.09 \\
1.63-9.66\end{array}$ \\
\hline Level of fragility & $\begin{array}{c}\text { Robust (ref.) } \\
\text { Pre-frail } \\
\text { Frail }\end{array}$ & $\begin{array}{c}- \\
0.251 \\
0.003\end{array}$ & $\begin{array}{l}1.00 \\
1.62 \\
3.78\end{array}$ & $\begin{array}{c}- \\
0.71-3.69 \\
1.57-9.08\end{array}$ \\
\hline $\begin{array}{l}\text { Physical functionality of the } \\
\text { elderly care recipient }\end{array}$ & $\begin{array}{c}0-6 \text { (ref.) } \\
7-12 \\
13\end{array}$ & $\begin{array}{c}- \\
0.016 \\
0.011\end{array}$ & $\begin{array}{l}1.00 \\
2.56 \\
2.84\end{array}$ & $\begin{array}{c}- \\
1.19-5.51 \\
1.27-6.32\end{array}$ \\
\hline $\begin{array}{l}\text { Cognitive functionality of the } \\
\text { elderly care recipient }\end{array}$ & $\begin{array}{c}0-0.5 \text { (ref.) } \\
1-2 \\
3\end{array}$ & $\begin{array}{c}- \\
0.054 \\
0.016\end{array}$ & $\begin{array}{l}1.00 \\
2.10 \\
2.38\end{array}$ & $\begin{array}{c}- \\
0.99-4.48 \\
1.18-4.83\end{array}$ \\
\hline Total Burden & $\begin{array}{c}\leq 19 \text { (ref.) } \\
20-27 \\
\geq 28\end{array}$ & $\begin{array}{c}- \\
0.010 \\
<0.001\end{array}$ & $\begin{array}{l}1.00 \\
2.69 \\
7.03\end{array}$ & $\begin{array}{c}- \\
1.26-5.72 \\
3.18-15.50\end{array}$ \\
\hline Subjective health assessment & $\begin{array}{c}\text { Good / Very Good (ref.) } \\
\text { Regular } \\
\text { Bad / Very bad }\end{array}$ & $\begin{array}{c}- \\
0.005 \\
0.003\end{array}$ & $\begin{array}{c}1.00 \\
2.45 \\
25.99\end{array}$ & $\begin{array}{c}- \\
1.31-4.59 \\
2.96-228.51\end{array}$ \\
\hline $\begin{array}{l}\text { Subjective health assessment } \\
\text { compared to the past }\end{array}$ & $\begin{array}{c}\text { Better (ref.) } \\
\text { Equal } \\
\text { Worse }\end{array}$ & $\begin{array}{c}- \\
0.531 \\
0.002\end{array}$ & $\begin{array}{l}1.00 \\
1.32 \\
4.35\end{array}$ & $\begin{array}{c}- \\
0.55-3.18 \\
1.71-11.09\end{array}$ \\
\hline $\begin{array}{l}\text { Subjective health assessment } \\
\text { compared to the others }^{\mathrm{a}}\end{array}$ & $\begin{array}{c}\text { Better (ref.) } \\
\text { Equal } \\
\text { Worse }\end{array}$ & $\begin{array}{c}- \\
0.014 \\
0.010\end{array}$ & $\begin{array}{l}1.00 \\
2.46 \\
4.11\end{array}$ & $\begin{array}{c}- \\
1.20-5.01 \\
1.40-12.05\end{array}$ \\
\hline
\end{tabular}

Notes. ${ }^{*}$ OR $($ Odds Ratio $)=$ Risk ratio for worse quality of life; $(n=50$ with $\leq 40, n=50$ with $41-47$ and $n=48$ with $\geq 48)$. IC $95 \%$ OR $=95 \%$ confidence interval for the risk ratio. Ref.: reference level. Models of proportional risks. ${ }^{a}=N=139$

Multivariate hierarchical logistic regression analysis was performed with four blocks. In block 1, the variables number of diseases, number of symptoms and levels of fragility were considered. In block 2 , the variables physical functionality and cognitive functionality of the elderly target of care were added. In block 3 , the burden and in block 4 , subjective evaluation of current health, compared with past and compared with others. The final model, presented in
Table 4, showed that the number of diseases, total burden and subjective health evaluation compared to the past were significantly associated with poorer quality of life in the total score. Older caregivers with the highest risk of worse quality of life were those with 3 or more diseases (4.7 times higher risk), those with medium or high burden (2.6 and 6.7 times higher risk), and those with worse health evaluation compared to the past (risk 5.9 times higher). 
Table 4

Hierarchical logistic regression analysis for worse quality of life $(N=130)$

\begin{tabular}{|c|c|c|c|c|}
\hline Selected Variables & Categories & $p$ & O.R.* & IC $95 \%$ O.R.* \\
\hline \multirow[t]{3}{*}{ Number of diseases } & 0 (ref.) & - & 1.00 & - \\
\hline & $1-2$ & 0.102 & 2.10 & $0.86-5.09$ \\
\hline & $\geq 3$ & 0.003 & 4.67 & $1.69-12.89$ \\
\hline \multirow[t]{3}{*}{ Total burden } & $\leq 19$ (ref.) & - & 1.00 & - \\
\hline & $20-27$ & 0.027 & 2.60 & $1.12-6.07$ \\
\hline & $\geq 28$ & $<0.001$ & 6.65 & $2.72-16.26$ \\
\hline \multirow{3}{*}{$\begin{array}{l}\text { Subjective health assessment } \\
\text { compared to the past }\end{array}$} & Better (ref.) & - & 1.00 & - \\
\hline & Equal & 0.202 & 2.05 & $0.68-6.19$ \\
\hline & Worse & 0.002 & 5.92 & $1.88-18.60$ \\
\hline
\end{tabular}

$*$ OR $($ Odds Ratio $)=$ Risk ratio for worse quality of life; $(n=46$ with $\leq 40, n=43$ with $41-47$ and $n=41$ with $\geq 48)$. IC $95 \%$ OR $=95 \%$ confidence interval for the risk ratio. Stepwise criteria selection of variables. Ref. $=$ reference level. Models of proportional risks.

\section{Discussion}

The objective of this study was to identify the association between double vulnerability and quality of life of elderly caregivers. Regarding gender, in this study there was no significant difference between men and women. In the study by Kim et al. (2015), with a sample of 14059 retirees aged 50 years and older from Russia, Poland and the Czech Republic, men scored significantly higher scores on quality of life than women. In contrast, in the study of Tampubolon (2015) using the sample of five waves of the English Longitudinal Study of Ageing (ELSA) with a population of the same age, women scored better in CASP-19 than men. These divergences in the data suggest that further deepening of gender issues is needed in the studies using the CASP-19. Other variables may have influenced these differences, such as cultural aspects, caregiver and health status, among others.

This study evaluated the relationship between aspects of elderly caregiver vulnerability and his / her quality of life. This relationship was evidenced by the results and some factors were more relevant. Previous studies with samples of caregivers of varying ages have highlighted the dependence on ADLs of the elderly being cared for as a factor related to poorer quality of life (Moon, Townsend, Whitlatch, \& Dilworth-Anderson, 2017) and caregiver satisfaction (Lu, Liu, \& Lou, 2015). In this study, such relationship was observed in the difference between terciles and in the univariate hierarchical logistic regression analysis, however, the variable did not remain in the multivariate model. When the elderly is very dependent on ADLs, the caregiver needs to perform more activities and care, or more intense activities. This greater demand generates greater burden of the caregiver and more time of care, directly impacting the quality of life. The fact that this variable did not remain in the final model indicates that for the elderly caregivers of this sample, this variable interferes with quality of life, but there are other variables that are more important in this relation.

Fragility was also a variable that did not remain in the final model, however, it was found a higher frequency of fragile caregivers among caregivers with worse quality of life. This association has been reported in previous studies.
Meta-analysis of Kojima, Iliffe, Jivraj and Walters (2016) showed that frail elderly have significantly lower scores on the physical and mental dimensions of quality of life than non-fragile ones. The negative association between quality of life and frailty was already expected, since physical health is one of the dimensions of quality of life. This study showed that this association is also true for elderly caregivers, although in this sample, fragility is not the most important variable for the determination of quality of life.

Although the variables described have demonstrated significant associations with the quality of life of the caregiver, the caregivers with worse quality of life were those who had three or more diseases, medium or high burden and perception of worsening in their health. This association of caregiver health and burden with aspects related to the psychological dimension of the caregiver's quality of life has already been verified in other studies. The burden was inversely associated with happiness (Hoefman, van Exel, Jong, Redekop, \& Brouwer, 2011), satisfaction with life (Dahlrup, Ekström, Nordell, \& Elmståhl, 2015), subjective well-being (Domínguez-Guedea \& Garcia, 2015), quality of life in general (Santos et al., 2014) and mental domain of quality of life (Litzelman et al., 2015; Yang, Hao, George, \& Wang, 2012). The association found in this study, which confirms previous studies, shows the importance of the role of perceived burden in the caregiver's quality of life.

In previous studies, the number of chronic diseases was associated with lower scores in the mental domain of quality of life (Yang et al., 2012) and with less positive affect (Savla, Roberto, Blieszner, Cox, \& Gwazdauskas, 2011). In these studies, the age of the sample varied widely and included both young and old caregivers. However, the study by Tomomitsu, Perracini and Neri (2014) evaluated only elderly caregivers and the results showed that caregivers with lower satisfaction and greater stress had more chronic illnesses than caregivers with lower satisfaction and lower stress. Thus, the association between chronic diseases and psychological dimensions of quality of life independent of age seems clear. Considering that older people are more likely to develop chronic diseases than young people (Campolina, Adami, Santos, \& Lebrão, 2013; Global Burden of Disease 
Study 2013 Collaborators, 2015; Pinto \& Neri, 2013), older caregivers seem to be more vulnerable to a worsening in the quality of life in this sense.

Regarding health self-assessment, poorer health selfassessment was negatively associated with caregiver happiness (Lutomski et al., 2015). However, this relationship refers to the overall health self-assessment. No studies were found that evaluated the health self-assessment related to the past in caregivers. Considering that the sample of the present study contemplates only elderly caregivers, and from the three types of health self-evaluation investigated, only the self-assessment compared to the past remained in the final model, it can be inferred that the very perception of health changes related to ageing can interfere with the assessment of quality of life.

This study aimed to assess whether the double vulnerability of the elderly caregiver is related to the psychological dimensions of the quality of life assessed by CASP-19. The results of the regression analysis seem to confirm this association, since variables of the two types of vulnerability studied remained in the final model. The variables directly related to the caring activity considered in this study were associated with the outcome variable, however, only the burden remained in the final model. This data indicates that the perception of burden has a greater weight in the quality of life than the care needs of the dependent elderly.

Regarding the health of the caregiver, all variables evaluated were associated with quality of life, but the number of chronic diseases and a specific aspect of health self-assessment were highlighted. Thus, it is possible to consider that in the evaluation of the quality of life of the elderly caregiver, the health condition has an important weight together with the perception of burden.

One result that deserves attention in this study is the health self-assessment related to the past. In most studies the health self-assessment is studied only related to current health. Here, however, the perception that health worsened was more relevant than current health perception. Considering that a greater health weakness is expected over the course of ageing, perhaps to study older caregivers, the perception of changes in health is a more relevant measure than just the assessment of immediate health.

It is concluded that this study has contributed to the understanding of the quality of life of elderly caregivers. This population has been increasing and presenting specificities that differ in part from the extensive literature on caregivers that initially developed studies with middle-aged women and, more recently, with caregivers at various moments of human development. However, this study had limitations. Because it is a non-probabilistic, non-multicentric sample that does not contemplate the main regions of Brazil, the results cannot be generalized for the entire population of elderly Brazilian caregivers.

Given the results and implications of this work, it is suggested that future studies: (1) consider the changes related to the development of the caregiver when analyzing other outcomes common to the caregiver's reality, such as burden, stress, physical and mental health, social and family relations of the caregiver, spirituality and management of time and care activities; (2) investigate in greater detail the caregiver's health self-assessment, perhaps this variable helps more in understanding the effects of care on different aspects of the caregiver's life; (3) carry out longitudinal studies that can analyze the caregiver's ageing and its consequences on the health and well-being of the caregiver in the care relationship.

\section{References}

Adelman, R. D., Tmanova, L. L., Delgado, D., Dion, S., \& Lachs, M. S. (2014). Caregiver burden: A clinical review. Journal of the American Medical Association, 311(10), 1052-1059. doi:10.1001/jama.2014.304

Bowling, A. (2005). Measuring health: A review of quality of life measurement scales (3rd ed.). Berkshire, United Kingdom: Open University Press.

Braz, E., \& Ciosak, S. I. (2009). O tornar-se cuidadora na senescência [Becoming caregiver in the old age]. Escola Anna Nery, 13(2), 372-377. doi:10.1590/S141481452009000200019

Brito, F. C., Nunes, M. I., \& Yuaso, D. R. (2007). Multidimensionalidade em gerontologia II: Instrumentos de avaliação. In M. P. Netto (Org.), Tratado de gerontologia (2a ed., pp. 133-148). São Paulo, SP: Atheneu.

Campolina, A. G., Adami, F., Santos, J. L. F., \& Lebrão, M. L. (2013). A transição de saúde e as mudanças na expectativa de vida saudável da população idosa: Possíveis impactos da prevenção de doenças crônicas [The health transition and changes in healthy life expectancy in the elderly population: Possible impacts of chronic disease prevention]. Cadernos de Saúde Pública, 29(6), 1217-1229. doi:10.1590/S0102-311X2013000600018

Carter, J. H., Lyons, K. S., Stewart, B. J., Archbold, P. G., \& Scobee, R. (2010). Does age make a difference in caregiver strain? Comparison of young versus older caregivers in early-stage Parkinson's disease. Movement Disorders, 25(6), 724-730. doi:10.1002/mds.22888

Dahlrup, B., Ekström, H., Nordel, E., \& Elmståhl, S. (2015). Coping as a caregiver: A question of strain and its consequences on life satisfaction and health-related quality of life. Archives of Gerontology and Geriatrics, 61(2), 261-270. doi:10.1016/j.archger.2015.06.007

Damasceno, A., Delicio, A. M., Mazo, D. F. C., Zullo, J. F. D., Scherer, P., Ng., R. T. Y., \& Damasceno, B. P. (2005). Validation of the Brazilian version of the MiniTeste CASI-S. Arquivos de Neuro-Psiquiatria, 63(2-B), 416-421. doi:10.1590/S0004-282X2005000300010 
Domínguez-Guedea, M. T., \& Garcia, A. O. (2015). Sociocultural and familial influences on the wellbeing of Mexican older adults' family caregivers. Research in Gerontological Nursing, 8(4), 188-196. doi:10.3928/19404921-20150219-02

Fonareva, I., \& Oken, B. S. (2014). Physiological and functional consequences of caregiving for relatives with dementia. International Psychogeriatrics, 26(05), 725-747. doi:10.1017/S1041610214000039

Fried, L. P., Tangen, C. M., Walston, J., Newman, A. B., Hirsch, C., Gottdiener, J., ... McBurnie, M. A. (2001). Frailty in older adults: Evidence for a phenotype. The Journals of Gerontology. Series A, Biological Sciences and Medical Sciences, 56(3), M146-156. doi:10.1093/gerona/56.3.M146

Global Burden of Disease Study 2013 Collaborators. (2015). Global, regional, and national incidence, prevalence, and years lived with disability for 301 acute and chronic diseases and injuries in 188 countries, 1990-2013: A systematic analysis for the Global Burden Disease Study 2013. The Lancet, 386(9995), 743-800. doi:10.1016/ S014-6736(15)60692-4

Hoefman, R. J., van Exel, N. J. A., Looren de Jong, S., Redekop, W. K., \& Brouwer, W. B. F. (2011). A new test of the construct validity of the CarerQol instrument: Measuring the impact of informal care giving. Quality of Life Research, 20(6), 875-887. doi:10.1007/s11136-010-9829-8

Hyde, M., Wiggins, R. D., Higgs, P., \& Blane, D. (2003). A measure of quality of life in early old age: The theory, development and properties of a needs satisfaction model (CASP-19). Aging \& Mental Health, 7(3), 186-194. doi:10.1080/1360786031000101157

Katz, S., Ford, A. B., Moskowitz, R. W., Jackson, B. A., \& Jaffe, M. W. (1963). Studies of illness in the aged. The Index of ADL: A standardized measure of biological and psychosocial function. Journal of the American Medical Association, 185(12), 914-919. doi:10.1001/ jama.1963.03060120024016

Kim, G. R., Netuveli, G., Blane, D., Peasey, A., Malyutina, S., Simonova, G., ... Pikhart, H. (2015). Psychometric properties and confirmatory factor analysis of the CASP19, a measure of quality of life in early old age: The HAPIEE study. Aging \& Mental Health, 19(7), 595-609. doi:10.1080/13607863.2014.938605

Kojima, G., Iliffe, S., Jivraj, S., \& Walters, K. (2016). Association between frailty and quality of life among community-dwelling older people: A systematic review and meta-analysis. Journal of Epidemiology and Community Health, 70(7), 716-721. doi:10.1136/jech-2015-206717

Lawton, M. P., \& Brody, E. M. (1969). Assessment of older people: Self maintaining and instrumental activities of daily living. The Gerontologist, 9(3 Pt. 1), 179-186. doi:10.1093/geront/9.3_Part_1.179
Lebrão, M. L., \& Duarte, Y.A. O. (2003). SABE-Saúde, Bemestar e Envelhecimento. O projeto SABE no Municipio de São Paulo: Uma abordagem inicial. Brasília, DF: OPAS.

Lino, V. T. S., Pereira, S. R. M., Camacho, L. A. D., Ribeiro Filho, S. T., \& Buksman, S. (2008). Adaptação transcultural da Escala de Independência em Atividades de Vida Diária (Escala de Katz) [Cross-cultural adaptation of the Independence in Activities of Daily Living Index (Katz Index)]. Cadernos de Saúde Pública, 24(1), 103112. doi:10.1590/S0102-311X2008000100010

Litzelman, K., Skinner, H. G., Gangnon, R. E., Javier Nieto, F., Malecki, K., \& Witt, W. P. (2015). The relationship among caregiving characteristics, caregiver strain, and health-related quality of life: Evidence from the Survey of the Health of Wisconsin. Quality of Life Research, 24(6), 1397-1406. doi:10.1007/s11136-014-0874-6

Lu, N., Liu, J., \& Lou, V. W. Q. (2015). Caring for frail elders with musculoskeletal conditions and family caregivers' subjective well-being: The role of multidimensional caregiver burden. Archives of Gerontology and Geriatrics, 61(3), 411-418. doi:10.1016/j.archger.2015.07.002

Lutomski, J. E., van Exel, N. J. A., Kempen, G. I. J. M., Moll van Charante, E. P., den Elzen, W. P. J., Jansen, A. P. D., ... Melis, R. J. F. (2015). Validation of the CareRelated Quality of Life Instrument in different study settings: Findings from The Older Persons and Informal Caregivers Survey Minimum DataSet (TOPICS-MDS). Quality of Life Research, 24(5), 1281-1293. doi:10.1007/ s11136-014-0841-2

McGoldrick, M., \& Shibusawa, T. (2016). O ciclo vital familiar. In F. Walsh (Org.), Processos normativos da família: Diversidade e complexidade (S. M. M. Rosa, Trad., pp. 375-398). Porto Alegre, RS: Artmed.

Montaño, M. B. M., \& Ramos, L. R. (2005). Validade da versão em português da Clinical Dementia Rating [Validity of the Portuguese version of Clinical Dementia Rating]. Revista de Saúde Pública, 39(6), 912-917. doi:10.1590/S0034-89102005000600007

Moon, H., Townsend, A. L., Whitlatch, C. J., \& DilworthAnderson, P. (2017). Quality of life for dementia caregiving dyads: Effects of incongruent perceptions of everyday care and values. The Gerontologist, 57(4), 657666. doi:10.1093/geront/gnw055

Neri, A. L., Yassuda, M. S., Moura, J. G. A., Araújo, L. F., Siqueira, M. E. C., Santos, G. A., ... Mantovani, E. P. (2013). A metodologia do Estudo Fibra Unicamp sobre fragilidade em idosos, em Belém, Parnaíba, Campina Grande, Poços de Caldas, Ermelino Matarazzo, Campinas e Ivoti. In A. L. Neri (Org.), Fragilidade e qualidade de vida na velhice: Dados do Estudo Fibra em Belém, Parnaíba, Campina Grande, Poços de Caldas, Ermelino Matarazzo, Campinas e Ivoti (pp. 3150). Campinas, SP: Alínea. 
Nunes, D. P., Duarte, Y. A. O., Santos, J. L. F., \& Lebrão, M. L. (2015). Rastreamento de fragilidade em idosos por instrumento autorreferido [Screening for frailty in older adults using a self-reported instrument]. Revista de Saúde Pública, 49(2). doi:10.1590/S00348910.2015049005516

Pearlin, L. I., Mullan, J. T., Semple, S. J., \& Skaff, M. M. (1990). Caregiving and the stress process: An overview of concepts and their measures. The Gerontologist, 30(5), 583-594. doi:10.1093/geront/30.5.583

Pinto, J. M., \& Neri, A. L. (2013). Doenças crônicas, capacidade funcional, envolvimento social e satisfação em idosos comunitários: Estudo Fibra [Chronic diseases, functional ability, social involvement and satisfaction in community-dwelling elderly: The Fibra study]. Ciência \& Saúde Coletiva, 18(12), 3449-3460. doi:10.1590/ S1413-81232013001200002

Rösler-Schidlack, B., Stummer, H., \& Ostermann, H. (2011). Health-related quality of life of family caregiversEvidence from Hesse. Journal of Public Health, 19(3), 269-280. doi:10.1007/s10389-010-0369-z

Santos, R. L., Sousa, M. F. B., Simões-Neto, J. P., Nogueira, M. L., Belfort, T. T., Torres, B., ... Dourado, M. C. N. (2014). Caregivers' quality of life in mild and moderate dementia. Arquivos de Neuro-Psiquiatria, 72(12), 931937. doi:10.1590/0004-282X20140155

Santos, R. L., \& Virtuoso Júnior, J. S. (2008). Confiabilidade da versão brasileira da escala de atividades instrumentais da vida diária [Reliability of the Brazilian version of the scale of instrumental activities of daily living]. Revista Brasileira em Promoção da Saúde, 21(4), 290-296. doi:10.5020/18061230.2008.p290

Savla, J., Roberto, K. A., Blieszner, R., Cox, M., \& Gwazdauskas, F. (2011). Effects of daily stressors on the psychological and biological well-being of spouses of persons with mild cognitive impairment. The Journals of Gerontology. Series B: Psychological Sciences and Social Sciences, 66(6), 653-664. doi:10.1093/geronb/gbr041

Scazufca, M. (2002). Brazilian version of the Burden Interview scale for the assessment of burden of care in carers of people with mental illnesses. Revista Brasileira de Psiquiatria, 24(1), 12-17. doi:10.1590/S151644462002000100006

Tampubolon, G. (2015). Delineating the third age: Joint models of older people's quality of life and attrition in Britain 2002-2010. Aging \& Mental Health, 19(7), 576583. doi:10.1080/13607863.2014.1003279

Tomomitsu, M. R. S. V., Perracini, M. R., \& Neri, A. L. (2014). Fatores associados à satisfação com a vida em idosos cuidadores e não cuidadores [Factors associated with satisfaction with life among elderly caregivers and non-caregivers]. Ciência \& Saúde Coletiva, 19(8), 34293440. doi:10.1590/1413-81232014198.13952013 van der Lee, J., Bakker, T. J. E. M., Duivenvoorden, H. J., \& Dröes, R.-M. (2014). Multivariate models of subjective caregiver burden in dementia: A systematic review. Ageing Research Reviews, 15, 76-93. doi:10.1016/j. arr.2014.03.003

Yang, X., Hao, Y., George, S. M., \& Wang, L. (2012). Factors associated with health-related quality of life among Chinese caregivers of the older adults living in the community: A cross-sectional study. Health and Quality of Life Outcomes, 10, 143. doi:10.1186/1477-7525-10-143

Zarit, S. H., Reever, K. E., \& Bach-Peterson, J. (1980). Relatives of the impaired elderly: Correlates of feelings of burden. The Gerontologist, 20(6), 649-655. doi:10.1093/ geront/20.6.649

Letícia Decimo Flesch is a Doctorate Degree in Gerontology from Universidade Estadual de Campinas, Campinas-SP, Brazil.

Samila Sathler Tavares Batistoni is a Professor in Escola de Artes, Ciências e Humanidades of Universidade de São Paulo, São Paulo-SP, Brazil.

Anita Liberalesso Neri is a Collaborator Professor in Departamento de Psicologia e Psiquiatria of Faculdade de Ciências Médicas of Universidade Estadual de Campinas, Campinas-SP, Brazil.

Meire Cachioni is an Associate Professor at Universidade de São Paulo, São Paulo-SP, Brazil.

Authors' Contribution:

All authors made substantial contributions to the conception and design of this study, to data analysis and interpretation, and to the manuscript revision and approval of the final version. All the authors assume public responsability for content of the manuscript.

Received: Jun. 27, 2016

1st Revision: Dec. 23, 2016

2nd Revision: Aug. 08, 2017

Approved: Nov. 16, 2017

How to cite this article:

Flesch, L. D., Batistoni, S. S. T., Neri, A. L., \& Cachioni, M. (2020). Elderly who care for elderly: Double vulnerability and quality of life. Paidéia (Ribeirão Preto), 30, e3003. doi:http://dx.doi.org/10.1590/1982-4327e3003 